\title{
Lemonia batavorum sp. nov. from the Netherlands, an overlooked sibling of $L$. dumi (Lepidoptera: Brahmaeidae)
}

\author{
Jan ŠUMPICH ${ }^{1)} \&$ Martin JAGELKA ${ }^{2)}$ \\ 1) Department of Entomology, National Museum, Cirkusová 1740, CZ-193 00 Praha 9 - Horní Počernice, Czech Republic; \\ e-mail: jansumpich@seznam.cz \\ ${ }^{2)}$ Karpatská 2, 90638 Rohožník, Slovakia; e-mail: martin.jagelka@googlemail.com
}

\author{
Accepted: \\ $2^{\text {nd }}$ November 2021 \\ Published online: \\ $24^{\text {th }}$ December 2021
}

\begin{abstract}
Barcoding of Dutch specimens of Lemonia dumi (Linnaeus, 1761) (Lepidoptera: Brahmaeidae) and a study of a large collection material of this species resulted in discovery of a new, hitherto undescribed species Lemonia batavorum sp. nov. Based on comparison with $L$. dumi, species level of $L$. batavorum sp. nov. is supported by the differences in its external appearance, differences in genitalia of both sexes and by $1.92 \%$ p-distance to $L$. dumi as the nearest neighbour. Photographs of specimens and genitalia of both sexes are given.
\end{abstract}

Key words. Lepidoptera, Brahmaeidae, Lemonia, barcoding, new species, taxonomy, Netherlands, Palaearctic Region

Zoobank: http://zoobank.org/ urn:1sid:zoobank.org:pub:6F1D87A2-ED14-450B-B92F-1BA807585FB5

(C) 2021 The Authors. This work is licensed under the Creative Commons Attribution-NonCommercial-NoDerivs 3.0 Licence.

\section{Introduction}

The family Brahmaeidae Swinhoe, 1892 comprises 68 species belonging to 6 genera including Lemonia Hübner, 1920 (Kitching et al. 2018). This genus was previously placed in Lemonidae Hampson, 1918, but recently the systematic position of the family was revised and according to the morphological characters and molecular phylogenetic studies, Lemonidae was synonymized with Brahmaeidae (Zwick 2008). Lemonia with 16 species occurring in the Palaearctic Region is one of the bombycoid genera which have not been fully revised so far. There are several smaller works from recent years that describe new taxa or present partial taxonomic modifications. Lemonia tamara Antoshin \& Zolotuhin, 2013 was described as a new species for science based on the material from Iran (ANTOSHIN \& ZolotuHin 2013), and Lemonia strigata Rougeot \& Viette, 1978 and L. ponticus Aurivillius, 1894 were removed from synonymy with $L$. taraxaci ([Denis \& Schiffermüller], 1775) and L. ballioni (Christoph, 1888) (ANTOSHIN \& Zolotuhin 2011, ZoLotuhin et al. 2017), respectively. All these acts were performed based on morphological characters in external appearance as well as their genitalia. Barcoding was used to distinguish particular Lemonia taxa only in exceptional cases (ANTOSHIN \& ZoLOTUHIN 2013) but in certain cases this method already confirmed the legitimacy of older taxonomic changes, e.g., the above mentioned removing of L. strigata from synonymy with $L$. taraxaci (p-distance between these species is 3.21\%) (the Barcode of Life Data Systems, BOLD; RATNASINGHAM \& HeBERT 2007). In the future comprehensive molecular analysis of this group can be expected because taxonomic positions of many Lemonia taxa remain hitherto unresolved (BOLD).

We obtained the eggs of $L$. dumi originating from the Netherlands (with all faunistic data) by exchange with an unknown entomologist at the entomological fair in Prague in 2016 without suspecting any taxonomic problem. First, a little different habitus of the larvae was suspicious, later when adults were reared, the differences in the external habitus in comparison with the typical $L$. dumi were obvious. Subsequently, one specimen was barcoded at the Canadian Centre for DNA Barcoding (CCDB) in 2018, and the result was surprising as it confirmed that the barcode of the Dutch specimen was not identical with L. dumi. In 2019, additional two specimens were barcoded in the same laboratory, and after uploading results on the BOLD System it was clear we could see a new, hitherto undescribed taxon. The aim of this paper is to present a description of the new species, based on external features of adults and their genitalia which support the genetic data. 


\section{Material and methods}

The adults were reared from eggs whose origin is unknown to us but most probably they were laid by a female collected in the field. Male and female genitalia were dissected and prepared using standard methods described by many authors, e.g., HUEMER \& KARSHOLT (2010).

Pinned specimens were photographed with a Canon $750 \mathrm{D}$ camera with a Canon EFS $60 \mathrm{~mm}$ lens. Slide-mounted genitalia in glycerol were photographed with a Canon EOS 1100D camera mounted on an Olympus BX41 stereomicroscope.

In total, three specimens of Dutch Lemonia were successfully barcoded at the Canadian Centre for DNA Barcoding (CCDB, Biodiversity Institute of Ontario, University of Guelph). In two cases we obtained the full 658 base-pair (bp) long segment of the 5' terminus of the cytochrome c oxidase gene and in one case a partial segment of 611 $\mathrm{bp}$; the sequences together with faunistic details of the sequenced specimens were uploaded at the BOLD (RATNASINGHAM \& HEBERT 2007) and are available as public. The sequences of the new species and other compared taxa were downloaded from BOLD using implemented Muscle multiple alignment algorithm (EDGAR 2004) and subsequently edited and analysed in MEGA X software (KUMAR et al. 2018). Tamura 3-parameter model (TAMURA 1992) with uniform rates was suggested as the best model for the data and it was used during the calculations of genetic distances and phylogenetic trees. Maximum likelihood method was used including 1000 bootstrap replications for the trees. We present the Barcode Index Numbers (BIN) according to RATNASINGHAM \& HEBERT (2013).

Abbreviations of private and institutional collections where the studied material is stored:

JAG Martin Jagelka, Research Collection, Rohožník, Slovakia; NMPC National Museum, Prague, Czech Republic;

ZMUC Zoological Museum, Natural History Museum of Denmark, Copenhagen, Denmark

\section{Systematic part}

\section{Lemonia batavorum sp. nov.}

(Figs 1-5, 16-17, 20-21, 24)

Lemonia dumi [misidentification]: SCHAFFERs (1995), Vos et al. (2007, 2008)

Type material. HoLOTYPe: (NMPC), NETHERLANDS: GELDERLAND: De Veluwe, Nationaal Park De Hoge Veluwe, ix. 2016 (ovo), reared x.2017, cultivated by M. Jagelka, collector unknown. PARATYPES:

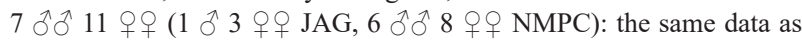
holotype, gen. prep. Šumpich 19904 (ㅇ), 21286 (ð), 21287 (ㅇ), 21289 (ð), (Barcode NMPC-Lep-0130, NMPC-Lep-0170, NMPC-Lep-0261)

Description. Adult. Male (Figs 1-3, 30). Wingspan $41-45 \mathrm{~mm}$. Head rusty brown, palpi labialis very short, densely covered with hairs of the same colour on tip but dark brown near base. Antenna dark brown, bipectinate, not ciliate. Eyes round, black. Thorax and abdomen with long rusty hairs. Forewing triangular with pointed apex. Ground colour dark brown with rusty hairs near base, fringes very short, rusty yellow. Discal spot usually small, round. Transverse line in two thirds of wing, very narrow, usually with sharp edges. Hindwings of the same ground colour but distinctly lighter near base, fringes short but longer than those of forewings, rusty yellow. Transverse line leads almost through middle of wing, broader, tapering posteriorly. Ventral side of both wings dark brown between transverse lines and margins of wings, basal area rusty-yellowish in forewing, darker in hindwings. Venation sometimes slightly suffused with yellowish scales.

Female (Figs 4-5, 29). Wingspan 44-52 mm. Similar to males, but larger wingspan and antennae with shorter arms.

Variation. None.

Male genitalia (Figs 16-17, 20-21). Uncus cask-shaped, comparatively long, tapering posteriorly, near base slightly narrowed, distinctly bilobed. Valvae nearly rectangular, dorso-apically rounded, ventral-lateral margin nearly right-angled. Juxta wide, only slightly bulging. Aedeagus straight, without cornuti.

Female genitalia (Fig. 24). Papilla analis broad, semioval, posterior apophysis $1.9 \times$ longer than anterior apophysis. Antrum cup-shaped with nearly straight edges, expanding proximally, distal part without sclerotized termination. Ductus bursae comparatively short, approximately of the same length as bursa copulatrix, membranous without sclerotization. Bursa copulatrix oval, without signa.

Larva (Figs 27-28). Caterpillars in final stage are coloured similarly to those of $L$. dumi (Figs 31-32) but have more brightly developed yellowish white stripes on body segments. Differential diagnosis. Lemonia batavorum resembles $L$. dumi in external appearance (Figs 6-15, 33), but the latter is generally paler and with ochre brown ground colour (rusty brown in L. batavorum), broader and yellow transverse lines of both wings (rusty yellow in L. batavorum), discal spot of different size and shape (round in L. batavorum), usually yellow basal part of costa (always dark in $L$. $b a$ tavorum), brown submarginal bands usually not reaching wing margin on upper side, and mainly apex of forewing darker in lighter specimens (whole submarginal band dark in L. batavorum); this is more significant in females. In male genitalia, $L$. batavorum differs in the shape of uncus (shorter and more convex laterally in $L$. dumi), valva (dorso-apical part more pointed in $L$. dumi) and juxta (rounded, distinctly more prominent in L. dumi) (Figs 18-19). In female genitalia, L. batavorum differs in the shape of antrum (bulbous and with sclerotized terminations in L. dumi), papillae analis round, posterior apophysis approximately $1.5 \times$ longer than anterior apophysis, and ductus bursae comparatively longer in $L$. dumi (Fig. 25).

Molecular data. BIN BOLD: AEA3525 $(n=3)$. The average intraspecific divergence of the barcode region is $0.0 \%$. Distance to the nearest neighbour is $1.92 \%$. (L. dumi [BIN BOLD: AAD9009; $n=13$ (7 public); records from Finland, Sweden, Czechia, Slovakia, Ukraine, Russia; the average intraspecific divergence of the barcode region is $0.37 \%$, maximum 0.64 $\%$ ]). For other details see Fig. 26 and Conclusions.

Etymology. The species name batavorum is given after Batavi, an ancient Germanic tribe that once inhabited the Gelderland region in the Netherlands (formerly called Batavia), from where the new species is described; noun in apposition. 


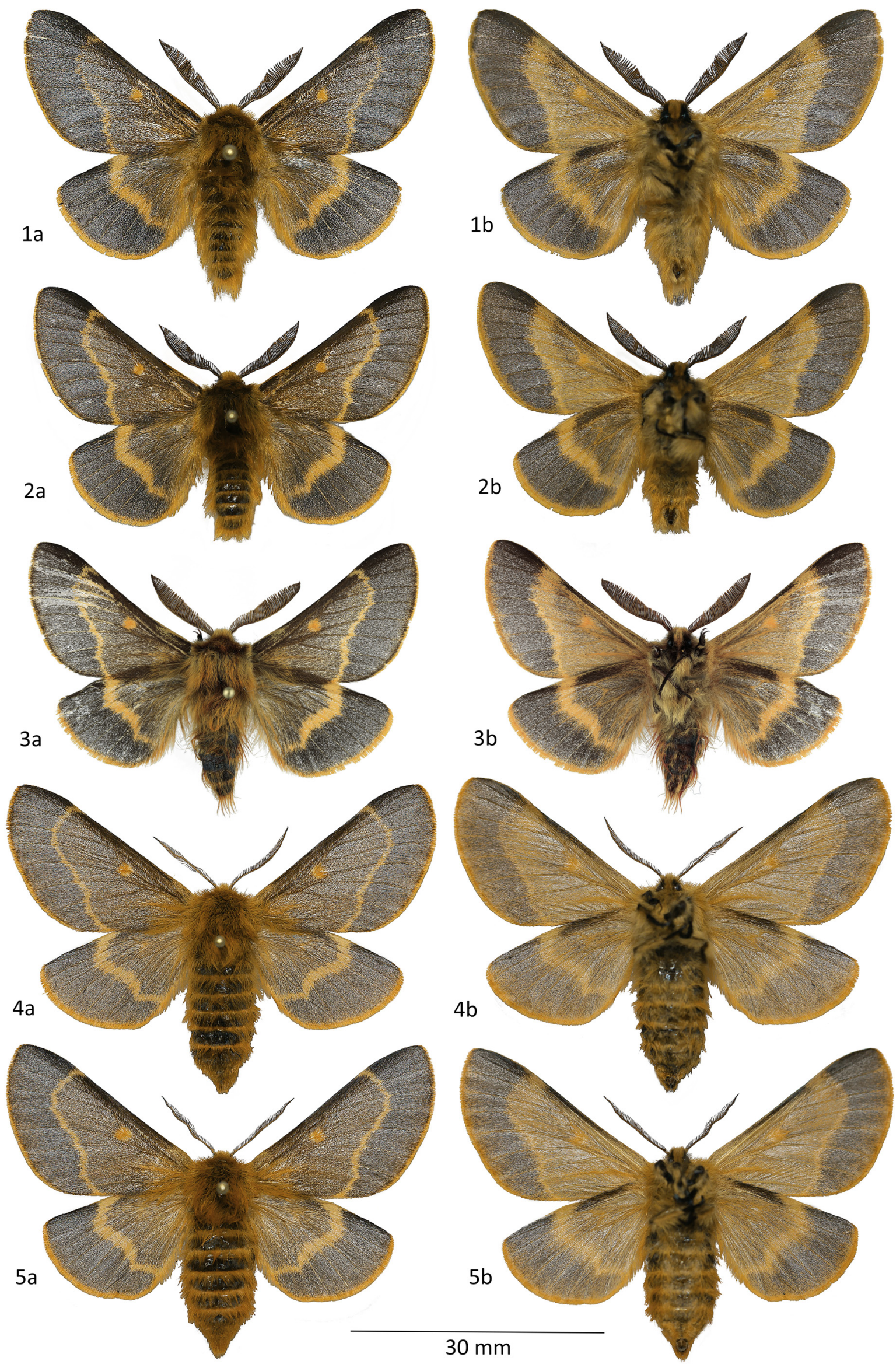

Figs 1-5. Habitus of Lemonia batavorum sp. nov., Netherlands, De Veluwe, x.2017, ex ovo (NMPC). 1 - holotype, male. 2-5 - paratypes: 2-3 - males; 4-5 - females ( $\mathrm{a}$ - dorsal view, $\mathrm{b}$ - ventral view). 


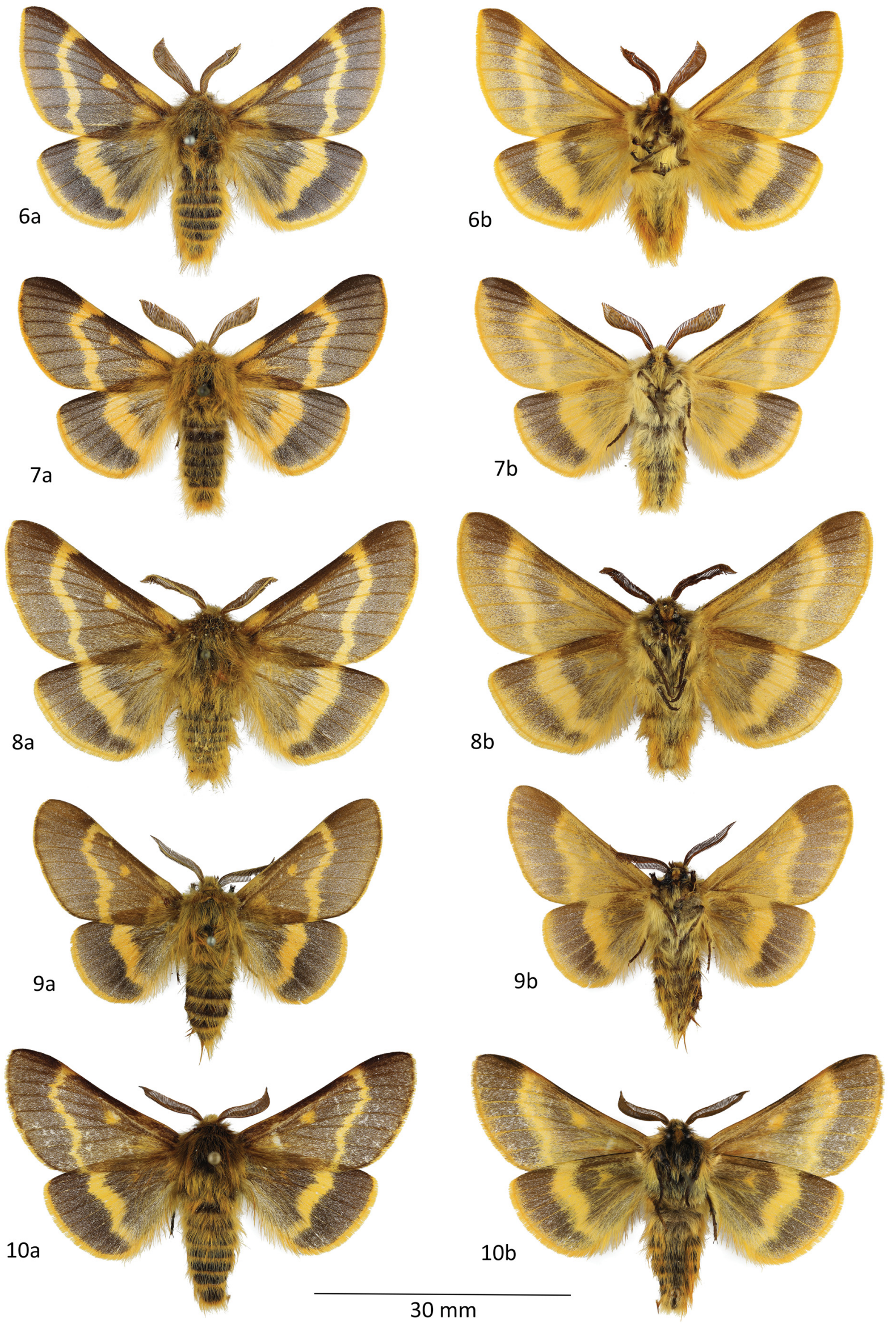

Figs 6-10. Habitus of Lemonia dumi (Linnaeus, 1761), males. 6 - Czechia, Bohemia, Jirny, 16.x.1932, F. Gemperle leg. (NMPC). 7 - Czechia, Moravia, Kuřim, 24.ix.1979, L. Traxler leg. (NMPC). 8 - Austria, Wien, 10.x.1940, F. Fischer leg. (NMPC). 9 - Switzerland, Menziken (without faunistic details) (NMPC). 10 - Denmark, Tibirke Bk., Sjælland RT, 16.x.1980, R. Torp (ZMUC) (a - dorsal view, b - ventral view). 


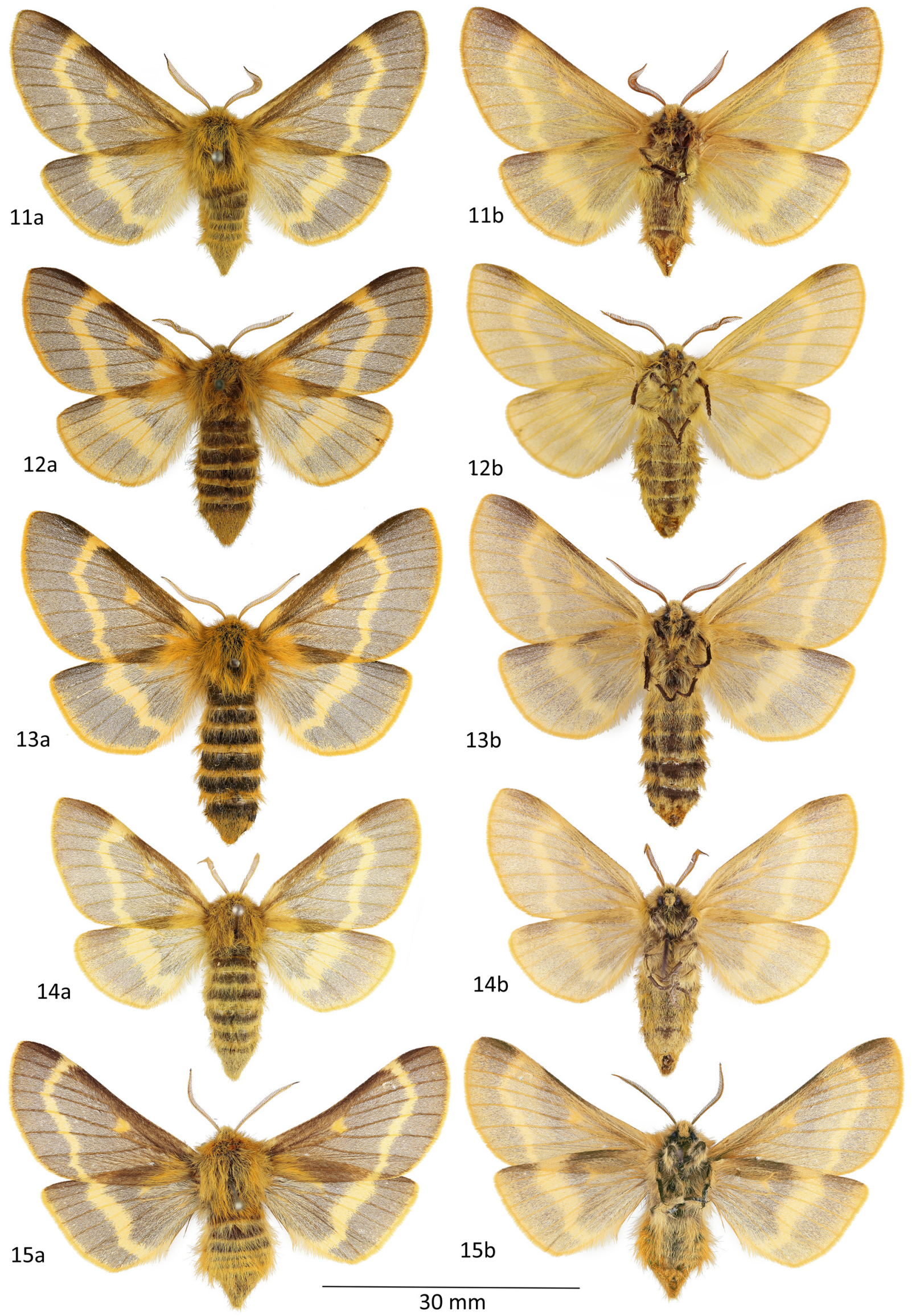

Figs 11-15. Habitus of Lemonia dumi (Linnaeus, 1761), females. 11 - Czechia, Bohemia, Jirny, 10.x.1933, A. Silbernagel leg. (NMPC). 12 - Czechia, Moravia, Kuřim, 16.ix.1979, L. Traxler leg. (NMPC). 13 - Slovakia, Gbelce, 27.x.1966, J. Marek (NMPC). 14 - Germany, Walheim (without faunistic details) (NMPC). 15 - Denmark, Tibirke Bk., Sjælland RT, 13.x.1955, H. K. Jensen (ZMUC) (a - dorsal view, b - ventral view). 


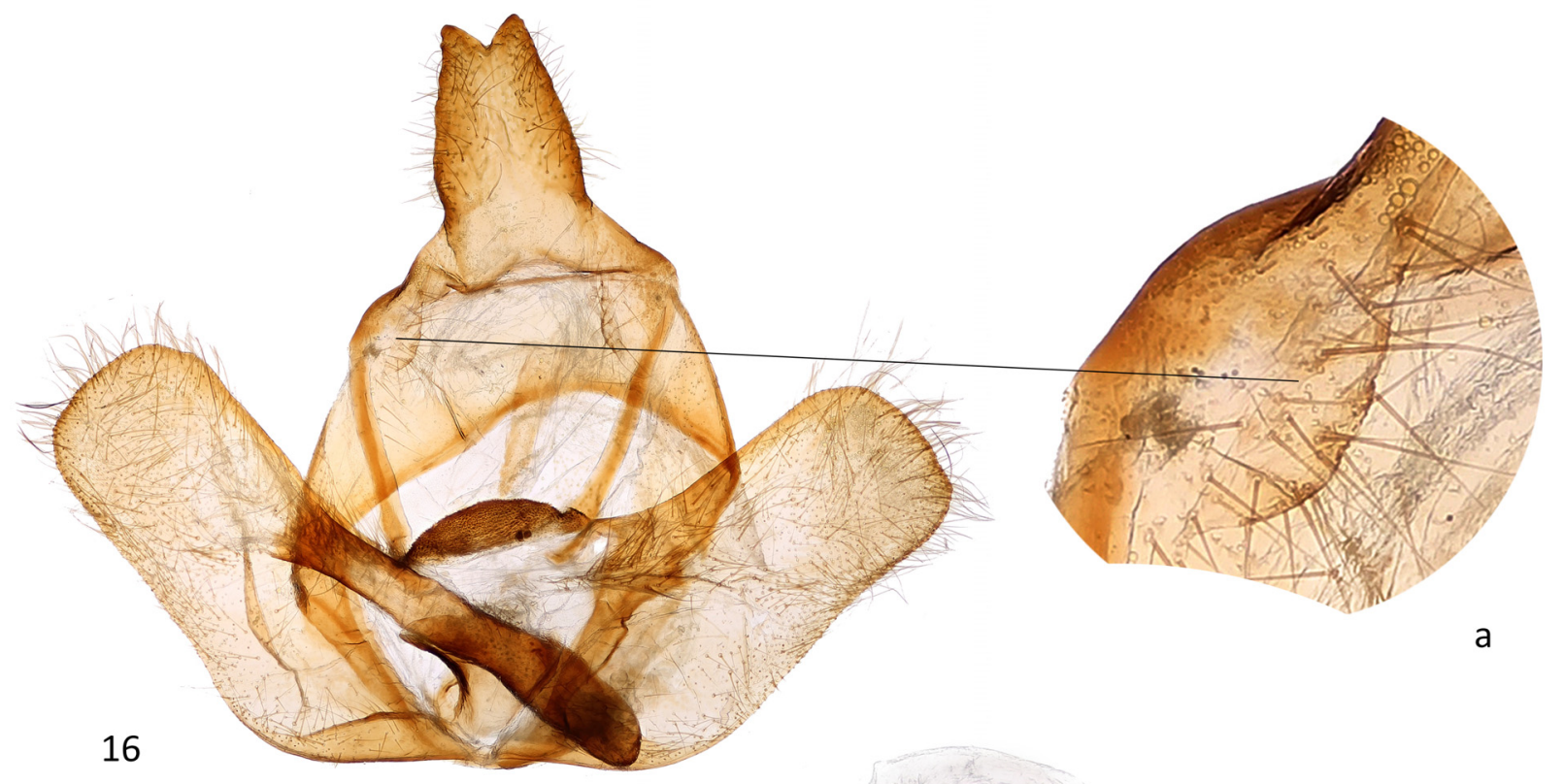

b

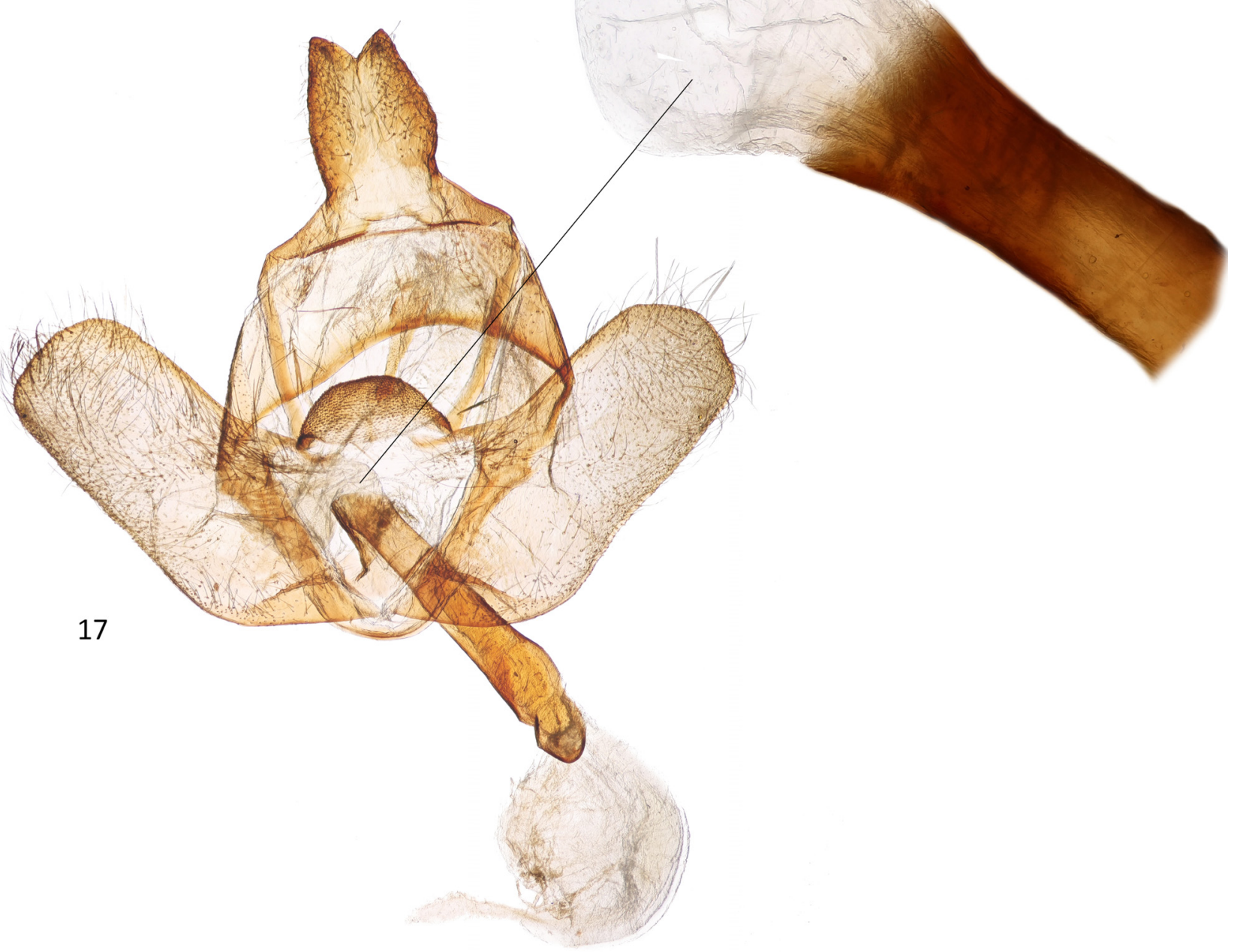

Figs 16-17. Male genitalia of Lemonia batavorum sp. nov., paratypes. 16 - gen. prep. SU21289; 17 - gen. prep. SU21286 (a - detail of socii, b - detail of the tip of aedeagus). 


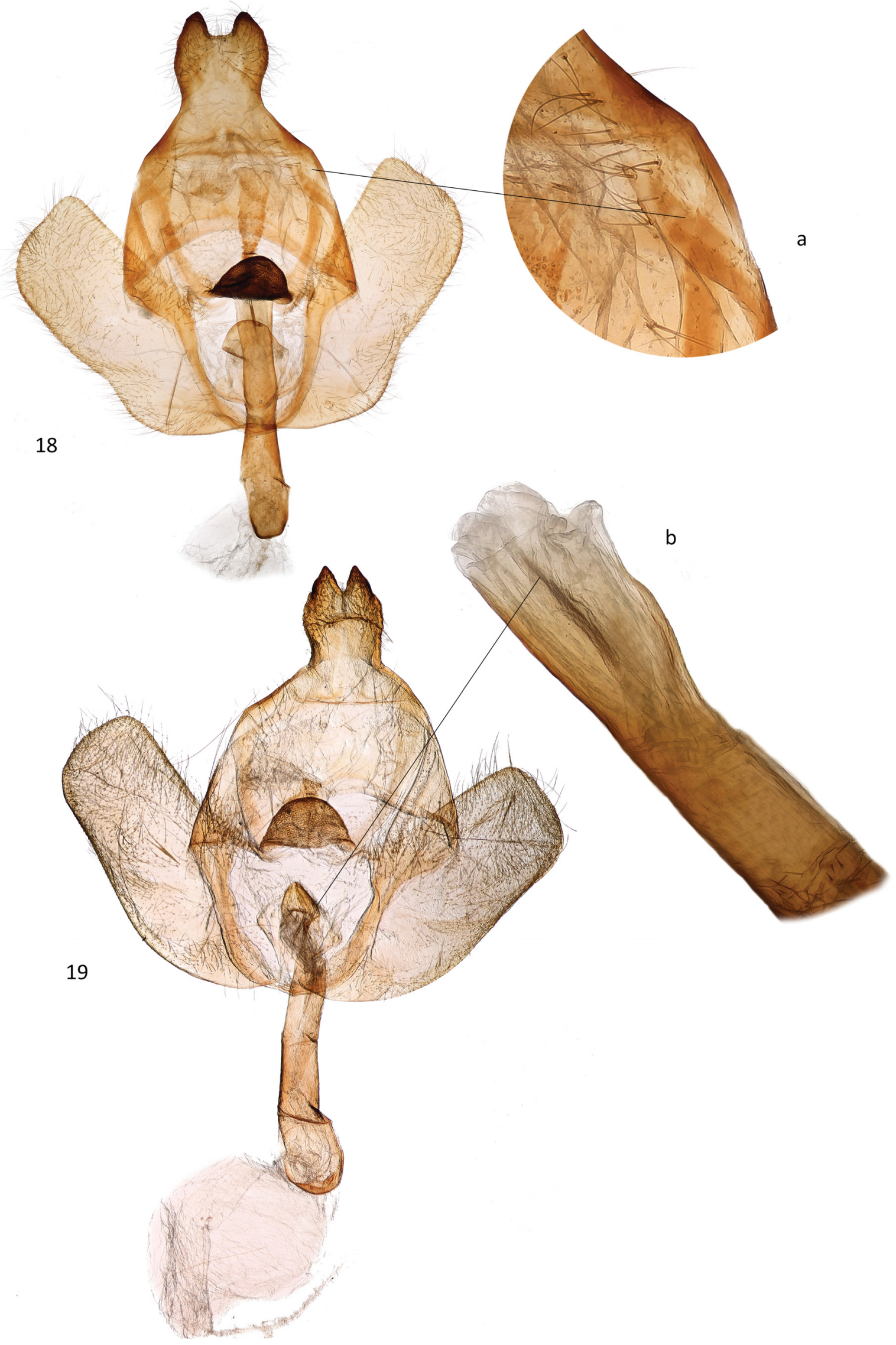

Figs 18-19. Male genitalia of Lemonia dumi (Linnaeus, 1761). 18 - Czechia, Moravia, Kuřim, gen. prep. SU21301; 19 - Slovakia, Pláštovce, gen. prep. SU21285 (a - detail of socii, $b$ - detail of the tip of aedeagus). 


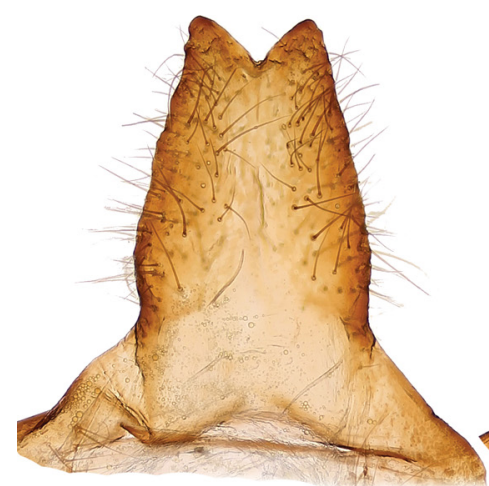

$20 a$

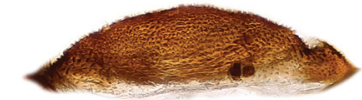

$20 b$

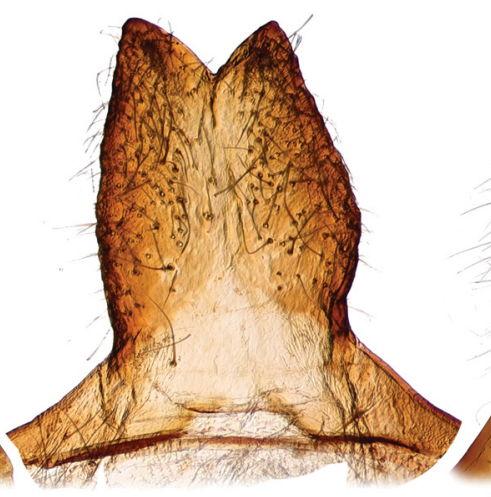

$21 a$

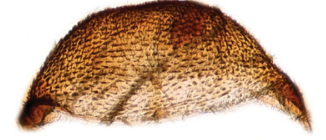

$21 b$

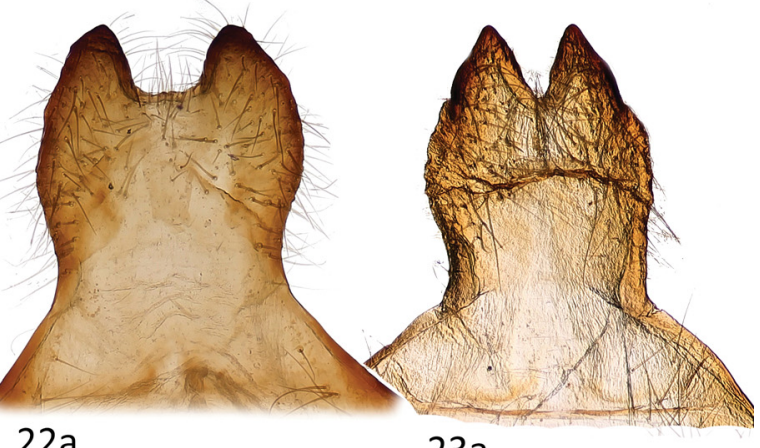

$23 a$

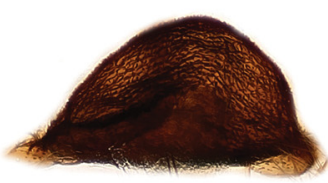

$22 b$

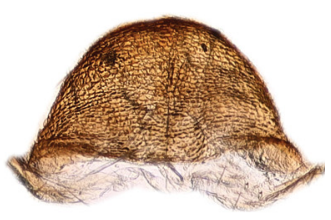

$23 b$

Figs 20-23. Comparison of uncus (a) and juxta (b) in male genitalia. 20-21 - Lemonia batavorum sp. nov.; 22-23 - L. dumi (Linnaeus, 1761).

Biology. In the National Park De Hoge Veluwe it occurs in sunny meadows and heathlands surrounded by pine trees, and on sandy soil with sparse grass, herbs and mosses according to SCHAFFERs (1995, as L. dumi). Hypochaeris radicata, Hieracium pilosella and Taraxacum officinale are mentioned as the food plants in the Netherlands (Vos et al. 2008, as L. dumi). In our breeding we gained the following knowledge of the species bionomy: eggs are rounded and similar to those of $L$. dumi but a little bit darker and comparatively larger in size. They are laid by females in several batches around the stems or twigs of dry plants close to the ground or even on the ground. Eggs overwinter and caterpillars hatch in March and April. After hatching from eggs, the caterpillars move a lot to find suitable plants to feed. We used Taraxacum sp., Sonchus sp. and Lactuca virosa as foodplants in captivity. Caterpillars feed during the day and night as well. Most of the time they are hidden on the ground where they are very well camouflaged. When mature, they bury themselves under the ground where they make a small chamber for pupation. We used a box with a layer of clay about $10 \mathrm{~cm}$ thick which was sufficient for pupation. Pupa is reddish brown. The moths hatched after 4-5 months but overwintering of pupa is probably also possible as it is sometimes seen in L. dumi. In our big "butterfly room" adults hatch in the morning hours, usually around 10:00 a.m. Flight period is in October, in nature depending on the weather. Adults have been seen flying even in very low temperatures (around $+6^{\circ} \mathrm{C}$ ). Males mostly fly around midday and they look for calling females. Males are much stronger and faster fliers than those of $L$. dumi and their flight is faster. Mating is short, lasting only 10 to 20 minutes. Females fly off after copulation and start to lay eggs. Unfortunately, breeding failed to continue for more than one generation.
Distribution. The Netherlands (SCHAFFERS 1995, Vos et al. 2008, this paper). It looks that the current distribution area is located only in the small north-western part of the country delimited by large rivers - the Waal in the south and the Ijssel in the east. In the past, L. dumi was reported also from Noord-Brabant in the south of the Netherlands but it has not been confirmed there since 1895 (Vos et al. 2008). According to SCHAFFERS (1995) the last occurrence of L. dumi in the Netherlands before discovery in Hoge Veluwe originated from Swalmen in the Limburg region from 1956. However, most probably all these records belong to L. dumi, not to L. batavorum, similarly to the records from Belgium and northern France (cf. LEBRUN 2007, JOSEPH \& JUGAN 2012). We also did not find any voucher specimens of L. batavorum from northwest Germany. The moths from Denmark definitely belong to $L$. dumi. We examined several specimens of $L$. dumi from a small area in North Zealand (coll. ZMUC) where it occurred in a large population in the past but it has not been collected there since 1980, and at present this species is considered most probably extinct within the whole Denmark (recent records from Denmark are based on more or less doubtful observations, without voucher specimens) (O. Karsholt, pers. comm.).

Remark. Lemonia dumi has not been protected in the Netherlands so far (Vos et al. 2008) although the species was very rare and potentially endangered there. Currently it occurs only in De Hoge Veluwe National Park (SCHAFFERS 1995; Vos et al. 2007, 2008) where it has been recorded on several sites (https://www.vlinderstichting.nl/vlinders/ overzicht-vlinders/details-vlinder/herfstspinner). Considering that the current Dutch populations are here placed to a separate species, its strict protection and especially active support of its habitats (or sites of its potential occurrence) is absolutely necessary to save its gene pool. 


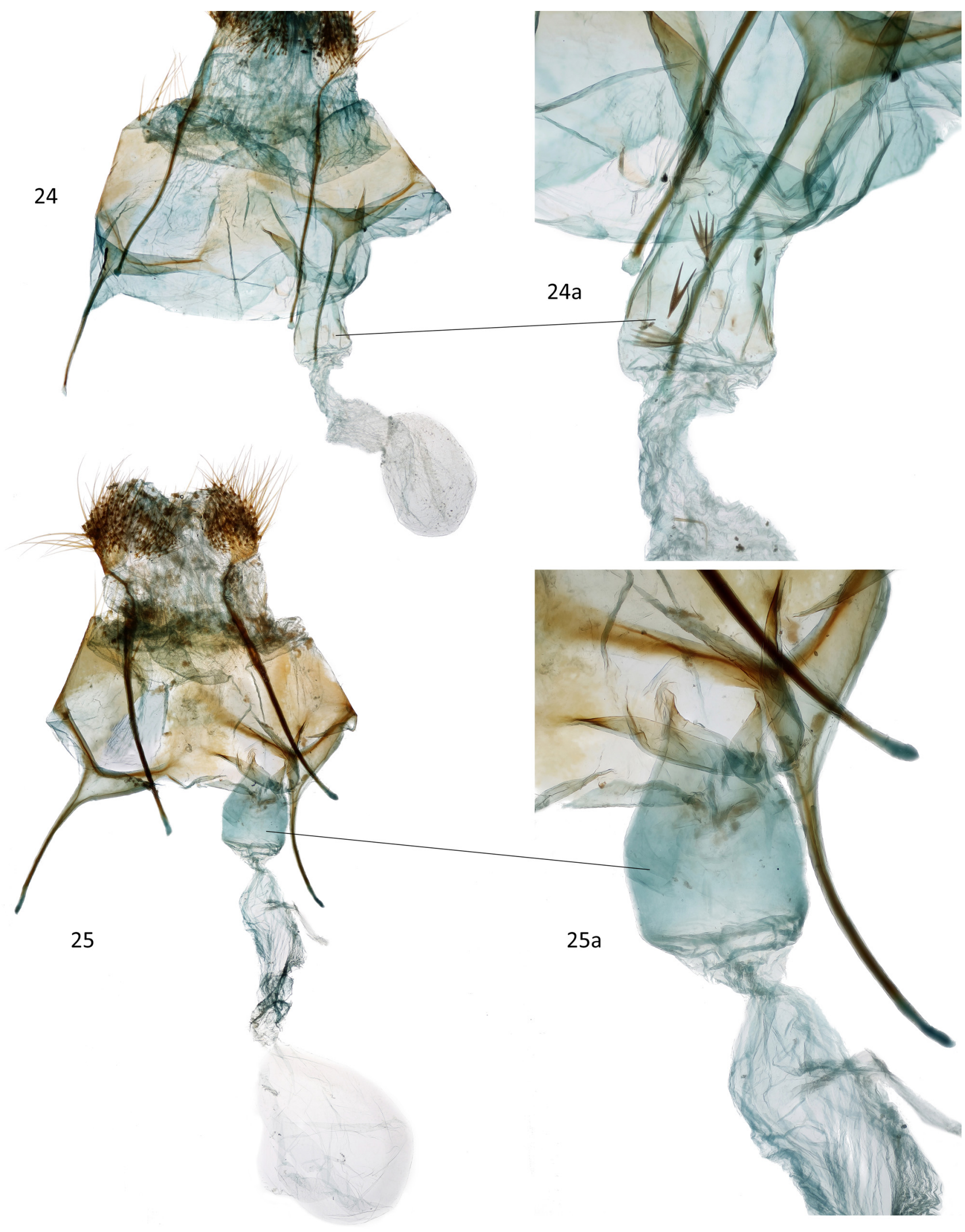

Figs 24-25. Female genitalia of Lemonia sp. 24 - L. batavorum sp. nov., paratype, gen. prep. SU19904; 25 - L. dumi (Linnaeus, 1761), Czechia, Moravia, Brno, gen. prep. SU21288. a - detail of ostium. 


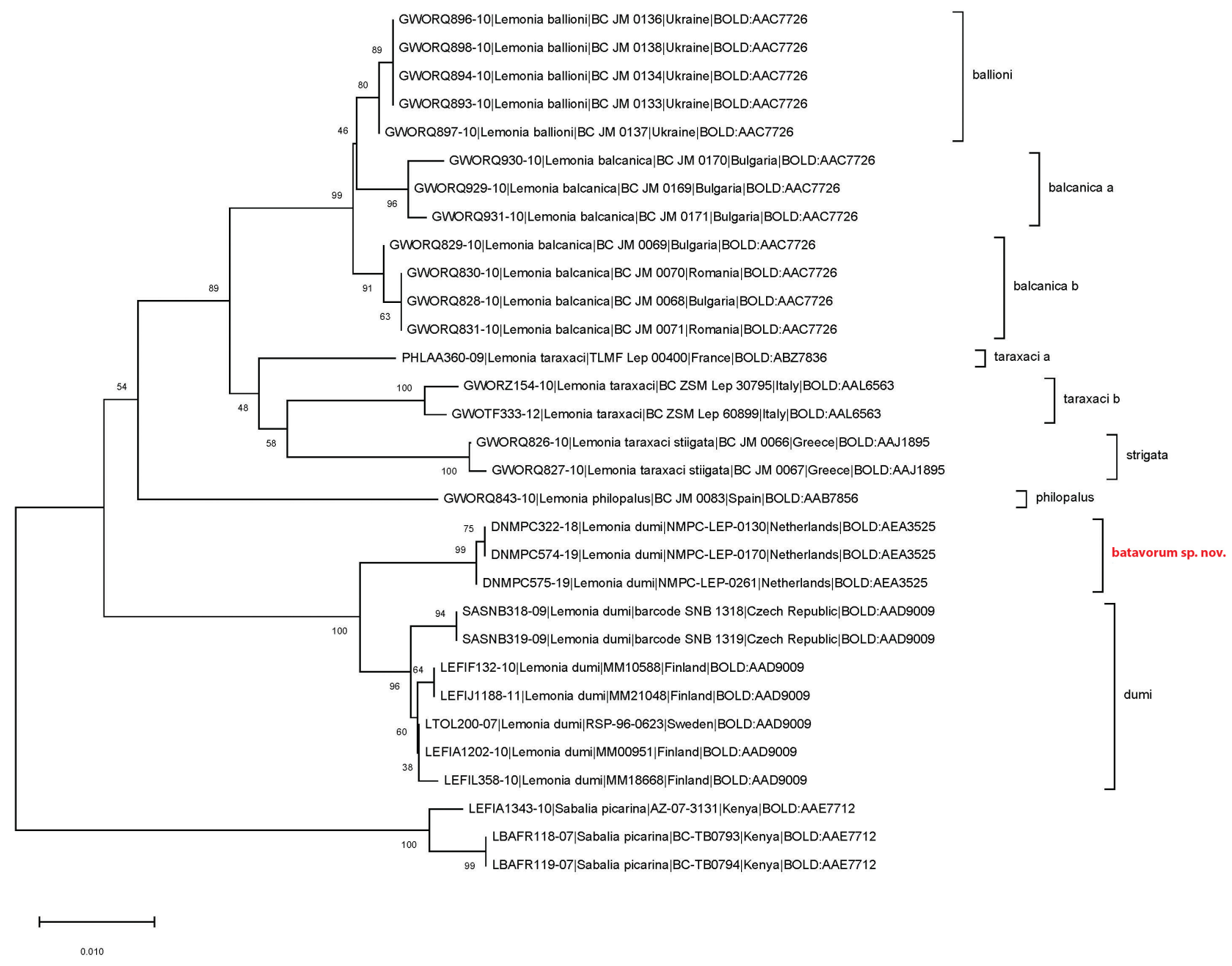

Fig. 26. Neighbor-joining tree based on public DNA barcodes of the Lemonia specimens with Sabalia picarina Walker, 1865 (Brahmaeidae) as an outgroup species (for sources see Material and methods).

\section{An updated checklist of Lemonia Hübner, 1920 with type area}

Distribution after ANTOSHIN \& ZoLOTUHIN (2011, 2013), LEPIFORUM (2021), WIKIPEDIA (2021).

L. balcanica (Herrich-Schäffer, 1844)

L. ballioni (Christoph, 1888)

L. batavorum sp. nov.

L. beirutica Daniel, 1965

L. dumi (Linnaeus, 1761)

L. pauli Staudinger, [1895]

L. peilei Rothschild, 1924

L. philopalus (Donzel, 1842)

L. pia Püngeler, 1902

L. ponticus Aurivillius, 1894

L. sacrosancta Püngeler, 1902

L. sardanapalus (Staudinger, 1887)

L. strigata Rougeot \& Viette, 1978

L. syriensis Daniel, 1953

L. tamara Antoshin \& Zolotuhin, 2013

L. taraxaci ([Denis \& Schiffernüller], 1

L. vallantini (Oberthür, 1890)

\section{Conclusions}

During the preparation of this paper, we dealt with a problem, whether the new taxon should be assigned to the species or subspecies level. Beside the fact that $L$. batavorum is easily distinguishable based on its external appearance we also considered its genetic relationship with other taxa. In Fig. 26 all public Lemonia records stored in the BOLD are compared. Even from this limited number of available records, the taxonomic position of some specimens is still open. Three separate clusters with the same BIN (AAC7726) most likely represent two genetic lineages of Lemonia balcanica (Herrich-Schäffer, 1844) mountain ("a", Rhodopi) and lowland ("b") one (p-distance between these clusters is $1.04 \%$ ), related to $L$. ballioni with not much significant difference in barcode but clearly a distinct species morphologically $(0.87 \%$ p-distance to $L$. balcanica "a" and $0.67 \%$ p-distance to L. balcanica "b"). It should be added that $L$. balcanica occurring in Turkey and Caucasus is also clustered independently (nonpublic data excerpted from the tree created by the BOLD), and its conspecificity with the Balkan populations needs to be confirmed. Detailed examination of adults and their genitalia is necessary to establish whether there is a complex of related taxa or only one species with wide barcode region. Similar study needs to be performed in $L$. taraxaci group (incl. $L$. taraxaci "a" and "b" in Fig. 26) to determine its taxonomic position (and most probably also in other species groups 

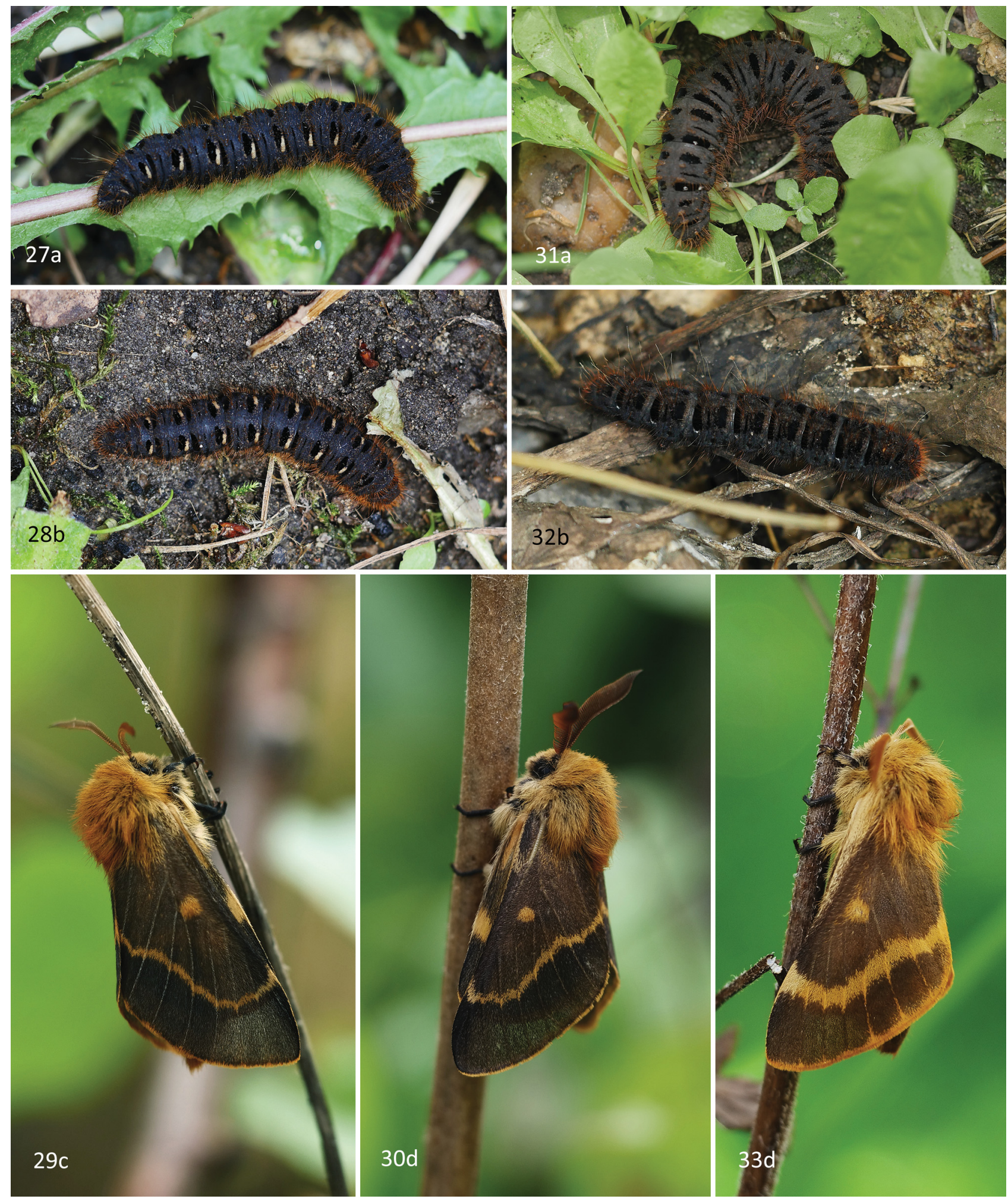

Figs 27-33. Comparative presentation of larvae and adults in natural position. 27-30 - Lemonia batavorum sp. nov.; 31-33 - L. dumi (Linnaeus, 1761) ( $\mathrm{a}$ - larva in dorsal view; $\mathrm{b}$ - larva in lateral view; $\mathrm{c}$ - adult, female; $\mathrm{d}$ - adult, male).

not named here). Thus, it is clear that distances of barcode regions cannot be the only criterion for determining the taxonomic position of a new taxon in this genus, but all features must be considered in context. We conclude that the distinct differences in habitus, genitalia of both sexes as well as a relatively big distance from the nearest neighbour (L. dumi) support our decision to describe L. batavorum as a species level taxon.

\section{Acknowledgements}

We express our thanks to an unknown collector who provided us with the eggs of L. batavorum and to Ole Karsholt (ZMUC, Copenhagen) who kindly provided us with valuable help with material of $L$. dumi from Denmark as well as the actual information on its occurrence in Denmark. We are grateful to Dominik Vondráček (NMPC, 
Prague) for valuable help with interpretation of the genetic results. We also thank to both reviewers, Dušan Žitňan (Ústav zoológie, SAV, Bratislava) and Aidas Saldaitis (Nature Research Centre, Vilnius), for their useful comments. Jitka Ansari (London, United Kingdom) helped us a lot with improvements and corrections of English. Jan Šumpich's work was supported by the Ministry of Culture of the Czech Republic (DKRVO 2019-2023/5.I.c, National Museum, 00023272).

\section{References}

ANTOSHIN D. A. \& ZOLOTUHIN V. V. 2011: Lemonia strigata Rougeot et Viette, 1978, stat. n., and L. ballioni (Christoph, 1888) (Lepidoptera: Lemoniidae) in a fauna of Europe with taxonomic notes on related species and description of a new subspecies. Eversmannia 25-26: 9-24.

ANTOSHIN D. A. \& ZOLOTUHIN V. V. 2013: Taxonomic remarks on the Lemoniidae (Lepidoptera) with description of a new species from Iran. Tinea 22: 168-174.

EDGAR R. C. 2004: MUSCLE: multiple sequence alignment with high accuracy and high throughput. Nucleic Acids Research 32(5): 1792-1797.

JOSEPH C. \& JUGAN D. 2012: Lemonia dumi L., la Brune du pissenlit: la fin d'un mythe (Lep. Brahmaeidae). Oreina 19: 16-19.

KITCHING I. J., ROUGERIE R., ZWICK A., HAMILTON C. A., ST LAURENT R. A., NAUMANN S., MEJIA L. B. \& KAWAHARAA. Y. 2018: A global checklist of the Bombycoidea (Insecta: Lepidoptera). Biodiversity Data Journal 6: 1-13.

KUMAR S., STECHER G., LI M., KNYAZ C. \& TAMURA K. 2018: MEGA X: Molecular Evolutionary Genetics Analysis across computing platforms. Molecular Biology and Evolution 35: 1547-1549. https: //doi.org/10.1093/molbev/msy096
LEBRUN J. 2007: Une observation remarquable pour la Picardie et le Nord de la France: Lemonia dumi (L., 1761) dans l'Oise (Lepidoptera Lemoniidae). L'Entomologiste 63(1): 27-29.

LEPIFORUM e. V. (ed.) 2021: Bestimmungshilfe für die in Europa nachgewiesenen Schmetterlingsarten. [http://lepiforum.org/wiki/ taxonomy/] (2008-2021; accessed 20 August 2021)

RATNASINGHAM S. \& HEBERT P. D. N. 2013: A DNA-based registry for all animal species: the Barcode Index Number (BIN) system. PLoS ONE 8(8) (e66213): 1-16.

SCHAFFERS J. 1995: De Herfstspinner weer in Nederland. [The Patrician's Shrub Moth back in the Netherlands]. Vlinders 10(2): 20-22 (in Dutch)

TAMURA K. 1992: Estimation of the number of nucleotide substitutions when there are strong transition-transversion and $\mathrm{G}+\mathrm{C}$-content biases. Molecular Biology and Evolution 9: 678-687.

VOS R. DE, ELLIS W., GROENENDIJK D., POST F. \& ZWIER J. 2008: Overzicht van in 2002-2005 waargenomen interessante macrovlinders, inclusief de trekvlinders (Lepidoptera). (Overview of interesting macroLepidoptera including migrating Lepidoptera recorded in the years 2002-2005) Entomologische Berichten (Amsterdam) 68: 158-169 (in Dutch, English summary).

VOS R. DE, ZWIER J. \& GROENENDIJK D. 2007: Overzicht van in 2001 waargenomen interessante macronachtvlinders (Lepidoptera). (Overview of interesting macro-moths (Lepidoptera) in The Netherlands in 2001). Entomologische Berichten (Amsterdam) 67: 27-33 (in Dutch, English summary).

WIKIPEDIA 2021: Lemonia. Wikipedia, The Free Encyclopedia. [https:// en.wikipedia.org/wiki/Lemonia] (accessed 20 August 2021).

ZWICK A. 2008: Molecular phylogeny of Anthelidae and other bombycoid taxa (Lepidoptera: Bombycoidea). Systematic Entomology 33: 190-209. 